\title{
Long term researches regarding the irrigation influence on sugarbeet crop in the Crisurilor Plain
}

\author{
Brejea Radu - Domuța Cristian \\ University of Oradea, Faculty of Environmental Protection, Oradea, Romania \\ rbrejea@yahoo.com
}

SUMMARY

\begin{abstract}
The paper is based on the researches carried out in the long term trial placed on the preluvosoil from Agricultural Research and Development Station Oradea, Crisurilor Plain in during 1976-2012.

The soil water reserve in 0-75 cm depth decreased bellow easily available water content every year and in 32\% of years the soil water reserve decreased bellow wilting point. For optimum water supply an irrigation rate of $2665 \mathrm{~m}^{3} \mathrm{ha}^{-1}$ (variation interval $500-5090 \mathrm{~m}^{3}$ ha ${ }^{-1}$ ) was needed.

The irrigation determined improving of water/temperature + light report (Domuta climate index) with $47.4 \%$ in average in the period May-September. A statistically very significant connection was quantified between this indicator and the yield.

Daily water consumption increased in the irrigated variant, the biggest difference in comparison with unirrigated variant was registered in August, 86\% in comparison with unirrigated variant. As consequence, the value of the total water consumption increased with $50 \%$, variation interval was $11-154 \%$. The irrigation covered $37.8 \%$ of total water consumption, the variation interval was $8.3 \%-67.9 \%$.

The yield level of the sugarbeet increased in average with 61\%, the variation interval was 9-227\%. Standard deviation was lower in the irrigated variant and this emphasizes an improve of the yield stability with $25.1 \%$. The sugar content of the sugarbeet roots from irrigated variant increased statistically very significantly in the droughty years and differs significantly in the rainy years.

Water use efficiency increased in the irrigated variant with 7\% and irrigation water use efficiency was between $7.9 \mathrm{~kg}_{\text {yield }}$ gain $1 \mathrm{~m}^{-3}$ irrigation water and $17.4 \mathrm{~kg}$ yield gain $1 \mathrm{~m}^{-3}$ irrigation water.

The positive influence of the irrigation on microclimate, water consumption, yield level, stability and quality and on water use efficiency sustain the need of the irrigation in sugarbeet from Crisurilor Plain.
\end{abstract}

Keywords: sugarbeet, irrigation, Domuța climate index, yield, water use efficiency

\section{INTRODUCTION}

The Crişurilor Plain was known for large surfaces with water logging but the land reclamation changed the area. (Domuţa, 200; Muntean et al., 2011) There was not a good correlation between plants water requirement and rainfall distribution. In this conditions the researches regarding the crops irrigation was started by Stepănescu E. in 1967 and the irrigation regime of sugarbeet (and other 4 crops) was established in the conditions of the chernozem from Girișu de Criș (Domuța, 2009b, 2011, 2012). In 1973, Stepănescu E. placed the research field for study of the soil water balance in Girişu de Criş. Starting 1976 the researches regarding the study of the soil water balance were placed in Oradea (Domuţa, 2010, 2011), for obtaining the optimum water consumption, ten to ten days the soil moisture was determined and the soil water reserve was maintained between easily available water content and field capacity (Grumeza et al., 1989).

The paper presents the results researches during 1976-2012 regarding optimum irrigation regime in sugarbeet, the irrigation influence on microclimate, water consumption, yield quantity and quality and water use efficiency in optimum irrigated sugarbeet. In the same time, the determination of the optimum values for daily water consumption permits the calculation of the "crop coefficient, Kc" used in sugarbeet irrigation scheduling (Bazza and Tayaa, 1999).

\section{MATERIAL AND METHODS}

The paper presents the researches carried out during 1976-2012 in the long term trial for soil water balance study placed in Agricultural Research and Development Station Oradea, Western Romania in the conditions of a preluvosoil. All the preluvosoil profile are acidic (6.11-6.8), humus content $(1.44-1.75 \%)$ is law and total nitrogen is low medium (0.127-0.157). After 37 years of good soil management, the soil phosphorus content became very good (from $22.0 \mathrm{ppm}$ to $150.8 \mathrm{ppm}$ ) on ploughed depth, potassium content (124.5 ppm) is medium.

There are a high hydro stability $(47.5 \%)$ of the aggregates $(\Phi=0.25 \mathrm{~mm})$ on ploughingland; the bulk density $\left(1.41 \mathrm{~g} \mathrm{~cm}^{-3}\right)$ indicates a low settling soil, total porosity is medium. On the subjacent depth of the ploughed layer the bulk density characterizes the soil like moderate and very settled and total porosity is low and very low. Hydraulic conductivity is high $\left(21.0 \mathrm{~mm} \mathrm{~h}^{-1}\right)$ on 0-20 cm; medium $\left(10.5 \mathrm{~mm} \mathrm{~h}^{-1} ; 4.4 \mathrm{~mm} \mathrm{~h}^{-1}\right)$ on $20-40 \mathrm{~cm}$ and $40-60 \mathrm{~cm}$ and very low $\left(1.0 \mathrm{~mm} \mathrm{~h}^{-1}\right)$ on $60-80 \mathrm{~cm}$ depth (Domuţa et al., 2012).

The source of irrigation water was a drill of $15 \mathrm{~m}$ depth. Irrigation water quality was very good: $\mathrm{pH}=$ 7.2; $\mathrm{Na}^{+}=12.9 ;$ mineral residue $=0.5 \mathrm{~g} \mathrm{l}^{-1} ; \mathrm{CSR}=-1.7$; $\mathrm{SAR}=0.52$.

In Romania, the watering depth for sugarbeet is fixed one, 0-75 cm for this area. Soil moisture on 0-75 cm depth was determined in ten days interval and monthly 
on $0-150 \mathrm{~cm}$ depth. In the irrigated variant, the moment of the irrigation use was applied when the soil water reserve on $0-75 \mathrm{~cm}$ depth decreased to easily available water content. On the $0-100 \mathrm{~cm}$ layer the value of the easily available water content (Wea) is of $19.7 \%$. Easily available water content was established in function of clay content (Brejea, 2009, 2010, 2011) using the formula: $\mathrm{Wea}=\mathrm{WP}+2 / 3$ (FC-WP); in wich: $\mathrm{FC}=$ field capacity $(24.3 \%)$ and $\mathrm{WP}=$ wilting point $(10.5 \%)$.

The microclimate of the sugarbeet was characterizated by Domuţa climate index (ICD):

$$
\mathrm{ICD}=\frac{100 \mathrm{~W}+12.9 \mathrm{~A}}{\sum \mathrm{t}+\mathrm{Sb}}
$$

In which :

$\mathrm{W}=$ water (rainfall, irrigation, ground water) $\mathrm{mm}$, $\mathrm{A}=$ air humidity $(\%)$,

$\sum \mathrm{t}=$ the sum of daily average temperature $\left({ }^{\circ} \mathrm{C}\right)$,

$\mathrm{Sb}=$ sunshine (hours).

The characterization class by ICD values are: $<3$ excessive drought; $3.1-5$ very droughty; $5.1-7$ drought; 7.1-9 medium drought; 9.1-12 medium wet; 12.1-15 wet I; $15.1-18$ wet II; $18.1-25$ wet III; $>25$ excessive wet.

The water consumption was determined by the soil water balance method. Water use efficiency was calculated like report between yield and water consumption. (Crăciun, 1990; Răcucu et al., 2012; Borza and Stanciu, 2010).

The experiment data were calculated using the variance analysis method (Domuţa, 2006).

\section{RESULTS AND DISCUSSION}

\section{Optimum irrigation regime}

Maintaining the soil water reserve on $0-75 \mathrm{~cm}$ depth between easily available water content and field capacity determined to use an average irrigation rate of $2665 \mathrm{~m}^{3} \mathrm{ha}^{-1}$; the lowest irrigation rate, $500 \mathrm{~m}^{3} \mathrm{ha}^{-1}$, was used in 1978 and 1997; the highest value of the irrigation rate was $5090 \mathrm{~m}^{3} \mathrm{ha}^{-1}$, was used in 2000. In avarage, the irrigation was applied 6 times; variation interval of the number of irrigations was 1-11 (table 1).

Table 1.

Optimum irrigation regime in sugarbeet (Oradea, 1976-2012)

\begin{tabular}{lccc}
\hline Specification & Average & $\begin{array}{c}\text { Minimum } \\
\text { value }\end{array}$ & $\begin{array}{c}\text { Maximum } \\
\text { value }\end{array}$ \\
\hline Irrigation rate $\left(\mathrm{m}^{3} \mathrm{ha}^{-1}\right)$ & 2665 & 500 & 5090 \\
Number of irrigations & 6 & 1 & $(2000)$ \\
& & $119,1997)$ & 11 \\
\hline
\end{tabular}

In average on the studied period the irrigation scheme used includes zero irrigation in April, 1/2 irrigation rate used in May and September, 1 irrigation rate used in June and 2 irrigation rates used in July and August (table 2).
Table 2.

The average scheme of irrigation applied in sugarbeet (Oradea, 1976-2012)

\begin{tabular}{cccc}
\hline Specification & April & May & June \\
Number of irrigations & 0 & $1 / 2$ & 1 \\
\hline Specification & July & August & September \\
Number of irrigations & 2 & 2 & $1 / 2$ \\
\hline
\end{tabular}

\section{Irrigation influence on microclimate}

There are different possibilities for climate characterization. One of them consists of the climate indicators use. The main climate indicators used in Romania are: de Martonne aridity index, Seleaninov coefficient, Hellman criterium, Teaci index, Palfai aridity index, Domuta climate index (Petrescu, 1999).

The Martonne aridity index is the most known climate indicator. Ciobanu et al. (2003) used this climate indicator for quantification the relationships between the climate conditions and the wheat yields obtained in a long term trial with fertilizers; the climate indicator 'Domuta climate index' was used too. The correlation coefficients for relationships climate - yield were bigger using Domuta climate index: $\mathrm{R}^{2}=0.9895$ vs $\mathrm{R}^{2}=$ 0.6846 in the variant without manure and $R^{2}=0.8802$ vs $\mathrm{R}^{2}=0.8522$. Palcut (2003) obtained better correlation coefficient using Domuta climate index in comparison with 'de Martonne aridity index' for quantification the relationship climate - yield of the maize hybrids. Domuta (2003) quantified the relationship climateyield using 'de Martonne aridity index', 'Seleaninov coefficient', hydroheliotermic index and Domuta climate index; the following order of the correlation coefficient was registered for climate indicators used: $\mathrm{R}^{2}=0.9319$ for Seleaninov coefficient, $\mathrm{R}^{2}=0.9225$ for hydroheliotermic index, $\mathrm{R}^{2}=0.8662$ for de Martonne aridity index (Domuţa, 2005).

As consequence for characterization of the microclimate created by the irrigation use, the climate indicator 'Domuta climate index' was used. In unirrigated condition, the sugarbeet microclimate was characterized "medium wet" in May, June, July and September and "medium drought" in August; in average on the May-September period the microclimate of the unirrigated sugarbeet was characterized like "medium wet". The irrigation use determined the increase of the "Domuta climate index" values with $12.2 \%$ in May, with $36,1 \%$ in June, with $76.2 \%$ in July, with $127.4 \%$ in August, with $12.4 \%$ in September and with $47.4 \%$ in average on the period May-September; in the month of the irrigation period, the microclimate characterization was "medium wet" in May and September, "wet" in June, July and August and "wet I" in average of the period MaySeptember (table 3).

There is a direct connection between microclimate conditions quantified by Domuta climate index and sugarbeet yields obtained in the unirrigated and irrigated variants. The best quantification was obtained using the exponential function: $\mathrm{y}=21.492 \mathrm{e}^{0,0728} \mathrm{x} ; \mathrm{R}^{2}=0.72^{\mathrm{xxx}}$. 
Irrigation influence on water/temperature + light raport (Domuta climate index (ICD) in sugarbeet (Oradea, 1976-2012)

\begin{tabular}{llcccccc}
\hline \multicolumn{1}{c}{ Variant } & \multicolumn{1}{c}{ Specification } & May & June & July & August & September & May - September \\
\hline Unirrigated & ICD value & 9.8 & 11.9 & 9.7 & 7.3 & 10.5 & 9.8 \\
& Characterization & Medium wet & Medium wet & Medium wet & Medium drowght & Medium wet & Medium wet \\
\hline \multirow{2}{*}{ Irrigated } & ICD value & 11.0 & 16.2 & 17.1 & 16.6 & 11.8 & 14.5 \\
& Characterization & Medium wet & Wet II & Wet II & Wet II & Medium wet & Wet I \\
\hline Difference \% & & 12.2 & 36.1 & 76.2 & 127.4 & 12.4 & 47.4 \\
\hline
\end{tabular}

\section{Irrigation influence on water consumption}

In the months with irrigation, the values of the daily water consumption increased in comparison with the values were determined in unirrigated sugarbeet the relative differences were of $21.0 \%$ in April, of $17 \%$ in May of $31 \%$ in June, of $60 \%$ in July, of $86 \%$ in August and of $61 \%$ in September. The maximum daily water consumption for unirrigated sugarbeet $\left(37.3 \mathrm{~m}^{3} \mathrm{ha}^{-1}\right.$ day $^{-1}$ ) was registered a month (June) before than the maximum value from irrigated variant (table 4).

The irrigation determined the increase of the total water consumption of the sugarbeet with $50 \%$, variation interval $11-154 \%$. The main covering source of the total water consumption was the rainfall registered during the vegetation period of the sugarbeet, $351.6 \mathrm{~mm}$; this source covered a $74 \%$ from total water consumption of the unirrigated sugarbeet (variation interval 38-99\%) and $49.8 \%$ from total water consumption of the irrigated sugarbeet (variation interval 15-89\%). In average in the studied period, the water used from soil reserve presented $25.4 \%$ from total water consumption of the unirrigated sugarbeet and $12.4 \%$ from total water consumption of the irrigated sugarbeet. In average in the studied period, the irrigation covered $37.8 \%$ from total water consumption of the sugarbeet in the optimum water provisionment variation interval $8.3-67.9 \%$ (table 5).

Direct link was quantified between the sugarbeet water consumption and yield obtained in unirrigated and irrigated variants. The mathematical expression of this link is: $\mathrm{y}=4.02224 \mathrm{x}^{1.3731} ; \mathrm{R}^{2}=0.7706$.

\section{Irrigation influence on yield level, stability and quality}

In average on the period 1976-2012, the irrigation determined yield gain of $25030 \mathrm{~kg} \mathrm{ha}^{-1}(61 \%)$. Across the years, the yield gains, the relative differences in comparison with unirrigated variant were between $9 \%$ and $227 \%$. The irrigation determined improving in yield stability because the standard deviation value decreased with $25.1 \%$ in comparison with unirrigated period, $6920 \mathrm{~kg} \mathrm{ha}^{-1}$ vs $9240 \mathrm{~kg} \mathrm{ha}^{-1}$ (table 6).

Table 4 .

Irrigation influence on daily water consumption in sugarbeet (Oradea, 1976-2012)

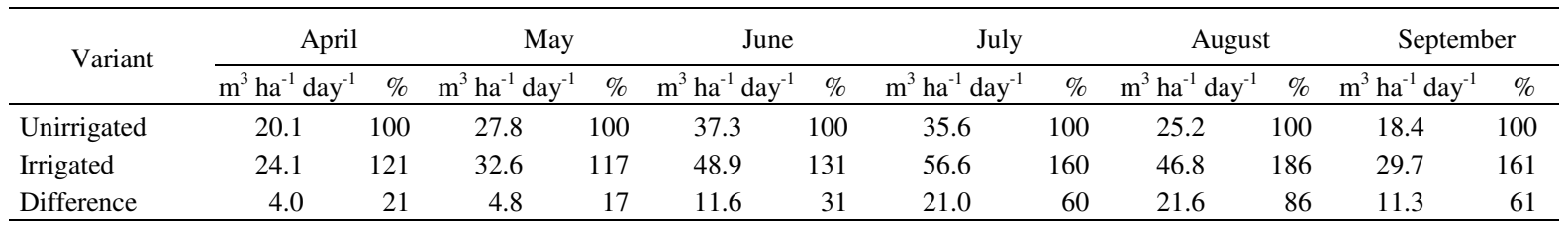

Table 5.

Irrigation influence on total water consumption $-\Sigma(e+t)$ in sugarbeet and the covering sources (Oradea, 1976-2012)

\begin{tabular}{|c|c|c|c|c|c|c|c|c|c|}
\hline \multirow{3}{*}{ Variant } & \multicolumn{3}{|c|}{$\sum(\mathrm{e}+\mathrm{t})$} & \multicolumn{6}{|c|}{ Covering sources of the water consumption } \\
\hline & \multirow{2}{*}{\multicolumn{2}{|c|}{ Average }} & \multirow[b]{2}{*}{$\begin{array}{c}\text { Variation } \\
\text { interval }(\%)\end{array}$} & \multirow[b]{2}{*}{$\begin{array}{l}\text { Soil water reserve } \\
\qquad\left(\mathrm{m}^{3} \mathrm{ha}^{-1}\right)\end{array}$} & \multicolumn{2}{|c|}{ Rainfall } & \multicolumn{3}{|c|}{ Irrigation } \\
\hline & & & & & $\left(\mathrm{m}^{3} \mathrm{ha}^{-1}\right)$ & $\begin{array}{c}\text { Variation } \\
\text { interval }(\%)\end{array}$ & $\left(\mathrm{m}^{3} \mathrm{ha}^{-1}\right)$ & $(\%)$ & $\begin{array}{c}\text { Variation } \\
\text { interval }(\%)\end{array}$ \\
\hline Unirrigated & 4714 & 100 & 100 & 1199 & 3516 & $38-99$ & - & - & - \\
\hline Irrigated & 7058 & 150 & $111-254$ & 877 & 3516 & $15-89$ & 2665 & 37.8 & $8.3-67.9$ \\
\hline
\end{tabular}

Table 6.

Irrigation influence on yield level and stability in sugarbeet (Oradea, 1976-2012)

\begin{tabular}{|c|c|c|c|c|c|c|}
\hline \multirow{2}{*}{ Variant } & \multicolumn{2}{|c|}{ Average yield } & \multicolumn{2}{|c|}{ Variation interval of the yields } & \multicolumn{2}{|c|}{ Standard deviation of the yields } \\
\hline & $\left(\mathrm{kg} \mathrm{ha}^{-1}\right)$ & $(\%)$ & $\left(\mathrm{kg} \mathrm{ha}^{-1}\right)$ & $(\%)$ & $\left(\mathrm{kg} \mathrm{ha}^{-1}\right)$ & $(\%)$ \\
\hline Unirrigated & 41360 & 100 & $18960-80900$ & 100 & 9240 & 100.0 \\
\hline
\end{tabular}

$\mathrm{LSD}_{5 \%}=53, \mathrm{LSD}_{1 \%}=970, \mathrm{LSD}_{0.1 \%}=1520$ 
There are different results regarding the irrigation influence on sugar content of the roots: Petrescu (1999) shows the positive influence of the water stress on sugar content; Bazza (1999) established the negative influence of the water stress on sugarbeet quality. Our researches were realized during 2009-2012 and show a higher sugar content in the irrigated variant. The differences are very significant statistically in the droughty years 2009, 2011 and 2012 and differ significant statistically in the rainy year 2010 . The relative differences were of $16 \%$ in $2009,7 \%$ in 2010 , $25 \%$ in 2011 and 24\% in 2012 (table 7).

\section{Irrigation influence on water use efficiency}

Two types of the indicators are known for establishing the water use efficiency. First type emphasizes the yield quantity obtained for $1 \mathrm{~m}^{3}$ water and the second type emphasizes the quantity of water used for 1 kilogram of main yield (Borza, 2006; Craciun, 1990; Domuta, 1995).

The paper presents the indicators 'water use efficiency' and 'irrigation water use efficiency'. They emphasize the quantity of yield obtain for $1 \mathrm{~m}^{3}$ of water used and quantity of the yield gain obtained for every $\mathrm{m}^{3}$ of irrigation water used. In average on the studied period, the irrigation determined the increase of the water use efficiency with $7 \%$. The maximum difference between irrigated variant and unirrigated variant $52 \%$, was registered in the very droughty year 2000. In the rainy year 1978, a negative difference of $-1 \%$ was registered (table 8 ).

In average on the studied period, the yield gain obtained for $1 \mathrm{~m}^{3}$ irrigation water was of $9.5 \mathrm{~kg} \mathrm{~m}^{-3}$. Variation interval was between $7.9 \mathrm{~kg}$ yield gain $\mathrm{m}^{-3}$ and $17.4 \mathrm{~kg}$ yield gain $\mathrm{m}^{-3}$ (table 8).

The irrigation influence on sugar content of the sugarbeet roots (Oradea, 1976-2012)

\begin{tabular}{|c|c|c|c|c|c|}
\hline Variant & \multicolumn{2}{|c|}{ Sugar content $(\%)$} & \multicolumn{2}{|c|}{ Difference $(\%)$} & Statistical significance $(\%)$ \\
\hline \multicolumn{6}{|c|}{$2009\left(\mathrm{LSD}_{5 \%} 0.32, \mathrm{LSD}_{1 \%} 0.65, \mathrm{LSD}_{0.1 \%} 1.05\right)$} \\
\hline Unirrigated & 14.5 & 100 & - & - & Control \\
\hline \multicolumn{6}{|c|}{$2010\left(\mathrm{LSD}_{5 \%} 0.39, \mathrm{LSD}_{1 \%} 0.74, \mathrm{LSD}_{0.1 \%} 1.20\right)$} \\
\hline Unirrigated & 16.1 & 100 & - & - & Control \\
\hline Irrigated & 17.2 & 107 & 1.1 & 7 & $* *$ \\
\hline Unirrigated & 14.7 & 100 & - & - & Control \\
\hline Irrigated & 17.3 & 125 & 2.6 & 25 & $* * *$ \\
\hline \multicolumn{6}{|c|}{$2012\left(\mathrm{LSD}_{5 \%} 0.29, \mathrm{LSD}_{1 \%} 0.57, \mathrm{LSD}_{0.1 \%} 0.98\right)$} \\
\hline Unirrigated & 13.7 & 100 & - & - & Control \\
\hline Irrigated & 17.0 & 124 & 3.3 & 24 & *** \\
\hline
\end{tabular}

Water use efficieny (WUE) and irrigation water use efficieny (IWUE) in sugarbeet (Oradea, 1976-2012)

\begin{tabular}{|c|c|c|c|c|c|c|}
\hline \multirow{3}{*}{ Variant } & \multicolumn{4}{|c|}{ WUE } & \multicolumn{2}{|c|}{ IWUE } \\
\hline & \multicolumn{2}{|c|}{ Average } & \multicolumn{2}{|c|}{ Variation interval } & Average & Variation interval \\
\hline & $\left(\mathrm{kg} \mathrm{m}^{-3}\right)$ & $(\%)$ & $\left(\mathrm{kg} \mathrm{m}^{-3}\right)$ & $(\%)$ & \multicolumn{2}{|c|}{$\left(\mathrm{kg}\right.$ yield gain $\left.\mathrm{m}^{-3}\right)$} \\
\hline Irrigated & 9.40 & 107 & $8.31-11.63$ & $99-152$ & 9.5 & $7.9-17.4$ \\
\hline
\end{tabular}

\section{CONCLUSIONS}

The researches were carried out during 1976-2012 the soil moisture was determined in ten days interval, for maintaining the soil water reserve between easily available water content and field capacity and an irrigation rate of $2665 \mathrm{~m}^{3} \mathrm{ha}^{-1}$ was needed.

The irrigation determined the improving of water/ temperature + light report (Domuta climate index) with $47.4 \%$ in average of the period May-September. Direct statistically very significant connection was quantified between this indicator and the yield.
Daily water consumption increased in the irrigated variant, the biggest difference in comparison with unirrigated variant was registered in August, 86\%. As consequence, the value of the total water consumption increased with $50 \%$, the variation interval with $11-$ $154 \%$. The irrigation covered $37.8 \%$ from total water consumption, variation interval was $8.3-67.9 \%$.

The yield level of the sugarbeet yield increased in average with $61 \%$, variation interval was $9-227 \%$. There was lower standard deviation value in irrigated variant and this emphasizes improve in yield stability with $25.1 \%$. The sugar content of the sugarbeet roots 
from irrigated variant increased very significantly statistically in the droughty years and differs significantly in the rainy years.

Water use efficiency increased in the irrigated variant with $7 \%$ and irrigation water use efficiency was between $7.9 \mathrm{~kg}$ yield gain $1 \mathrm{~m}^{-3}$ irrigation water and
$17.4 \mathrm{~kg}$ yield gain $1 \mathrm{~m}^{-3}$ irrigation water. The positive influence of the irrigation on microclimate, water consumption, yield stability and quality and on water use efficiency sustain the need of the irrigation in sugarbeet from Crisurilor Plain.

\section{REFERENCES}

Bazza, M.-Tayaa, M. (1999): Contribution to improve sugar beet deficit-irrigation. [In: Kirda, C. (et al.) (eds.) Crop yield response to deficit irrigation.] Kluwer Academic Publishers. Dordrecht. The Netherlands.

Borza, I.-Stanciu, A. (2010): Fitotehnie. Editura Universităţii Oradea. 75-94.

Brejea, R. (2009): Tehnologii de protecţie sau refacere a solurilor. Editura Universităţii din Oradea

Brejea, R. (2010): Ştiinţa solului - îndrumător de lucrări practice. Editura Universităţii din Oradea. 84-105.

Brejea, R.-Domuța, C. (2011): Practicum de pedologie. Editura Universităţii Oradea.

Crăciun, M. (1990): Cercetări privind raţionalizarea consumului de îngrăşăminte, apă, energie în funcţie de metodele de irigare. Teză de doctorat. ASAS Bucureşti. 120-142.

Domuța, C. (2003): Oportunitatea irigaţiilor în Câmpia Crişurilor. Editura Universităţii din Oradea. 56-89.

Domuţa, C. (2005): Irigarea culturilor. Editura Universităţii din Oradea. 31-49, 256-260.

Domuţa, C. (2006): Tehnică experimentală. Editura Universităţii din Oradea. $112-150$.

Domuţa, C. (2009): Irigarea culturilor. Editura Universităţii din Oradea. $88-110$.

Domuța, C. (coord.) (2009): Irigațiile în Câmpia Crişurilor. Editura Universităţii din Oradea.

Domuţa, C.-Sandor, M. (coord.) (2011): Relaţii în sistemul sol-apăplantă-atmosferă în Câmpia Crişurilor. Editura Universităţii din Oradea. 95-112.
Domuța, C. et al. (2012): Irigarea culturilor în Câmpia Crişurilor. Editura Universităţii din Oradea. 75-89.

Domuţa, Cr. (2010): Cercetări privind influenţa irigaţiei asupra culturilor de porumb, soia şi sfeclă de zahăr în condiţiile Câmpiei Crişurilor. Teză de doctorat Universitatea de Ştiinţe Agricole şi Medicină Veterinară Cluj-Napoca. 65-84.

Domuța, Cr--Domuta, C. (2010): Materii prime vegetale. Editura Universităţii din Oradea. 58-92.

Domuța, Cr. (2011): Subasigurarea cu apă a porumbului, soiei şi sfeclei de zahăr din Câmpia Crişurilor. Editura Universităţii din Oradea. 89-143.

Grumeza, N. et al. (1989): Prognoza şi avetrizarea udărilor în sistemele de irigaţii. Ed. Ceres Bucureşti.

Muntean, L. S.-Cernea, S.-Morar, G.-Duda, M.-Vârban, I.Muntean, S. (2011): Fitotehnie. Editura Risoprint Cluj-Napoca.

Petrescu, E. (1999): Cercetări privind reducerea consumului de apă la cultura de sfeclă de zahăr irigată în condiţiile pedoclimatice ale Câmpiei Crişurilor. Teză de doctoratn ASAS. Gh.I. Şişeşti. Bucureşti. 54-88.

Răducu, D.-Martini, A.-Pagliai, M.-Vignozzi, N.-Surdu, I.-Ipatie, J. (2012): Micromorphology as a method of assessing the mountain soil sensitivity in order to elaborate the meliorative technology friendly to environment and biodiversity. Analele Universităţii din Craiova. Agricultură-Montanologie-Cadastru. Lucrări Ştiinţifice. 42. 
